\title{
Relationship Between Number of Ovipositions of Cotesia flavipes (Cam.) and Number of Descendants Emerged from Its Host Diatraea saccharalis (Fabr.)
}

\author{
Meire N. Yamauchi ${ }^{1}$, Nivar Gobbi ${ }^{1}$, José Chaud-Netto ${ }^{2}$ and Ana E. Campos-Farinha ${ }^{2}$ \\ ${ }^{1}$ Departamento de Ecologia, UNESP, Caixa postal 199, 13506-900, Rio Claro, SP. \\ ${ }^{2}$ Departamento de Biologia, UNESP, Caixa postal 199, 13506-900, Rio Claro, SP.
}

An. Soc. Entomol. Brasil 26(1): 87-91 (1997)

Relação entre o Número de Oviposições de Cotesia flavipes (Cam.) e o Número de Descendentes que Emergem de seu Hospedeiro Diatraea saccharalis (Fabr.)

RESUMO - Fêmeas de Cotesia flavipes (Cam.) foram introduzidas, individualmente, em placas de Petri contendo uma larva de seu hospedeiro Diatraea saccharalis (Fabr.). Permitiu-se que cada fêmea de C. flavipes realizasse posturas uma ou duas vezes em uma mesma larva. O período de emergência das larvas e dos adultos, a razão sexual, o número de larvas e pupas inviáveis e a longevidade dos adultos de C. flavipes registrados nas duas condições experimentais (uma ou duas posturas) foram comparados. Os resultados revelaram que duas oviposições sucessivas no hospedeiro não alteraram a razão sexual na descendência, mas aumentaram o número de parasitóides e também o número de larvas e pupas inviáveis.

PALAVRAS-CHAVE: Insecta, parasitóide, superparasitismo, razão sexual, viabilidade.

\begin{abstract}
Females of Cotesia flavipes (Cam.) were individually introduced into Petri dishes containing one larva of its host Diatraea saccharalis (Fabr.). Each C. flavipes female was allowed to oviposit once or twice in the same larva. Time of emergence of larvae and adults, sex-ratio, number of non-viable larvae and pupae, and longevity of adults of $C$. flavipes were recorded. Data revealed that two successive ovipositions in the host did not affect sex-ratio, but increased number of parasitoids and number of non-viable larvae and pupae.
\end{abstract}

KEY WORDS: Insecta, parasitoid, superparasitism, sex-ratio, viability.

The success of a host-parasitoid relationship depends upon factors such as habitat location, searching, selection and parasitoid capacity to regulate the host physiologically (Doutt 1959, Vinson \& Iwantsch 1980, Stoltz \& Guzo 1986, Lawrence \& Akin 1990). Multiple ovipositions (superparasitism) does occur among parasitoids, with this behavior being dependent upon host density and having adaptive value (van Dyken \& Waage 1987, Hailemichael et al. 1994). Competition among offspring as a result of superparasitism or multiparasitism may occur in relation to available food. In this case, the resultant adults may have their fitness reduced (Hofsvang 1990). This selection of a host by a parasitoid is ba- 
sed on the age or instar of the host and a possible perception of equilibrium between amount and quality of food supply for its progeny (Vinson \& Iwantsch 1980, Sato 1980, Gobbi \& Cunha 1983, Hopper\& King 1984, Hagley \& Barber 1986, Hebert \& Cloutier 1990).

The sugar-cane borer, Diatraea saccharalis (Fabr.), is a key pest of sugar-cane in the Americas (Gilford \& Mann 1967, Alam et al. 1971, Galichet 1971, Cueva et al. 1980, Gálio 1980, Macedo et al. 1993).Damage occurs by mechanical action as the borer builds internal galleries, causing apical bud death and consequent lateral budding, weight loss, atrophy, and contamination by yeasts that cause red rottenness. Because of the simultaneous presence of all developmental stages of the pest throughout the year and the impossibility of using insecticides to control this borer, a biological control program through releases of the parasitoid Cotesia flavipes (Cam.) was established in Brazil, resulting in substantial reduction of sugar-cane yield losses and the improvement of raw material produced (Alam et al. 1971, Botelho et al. 1983, Botelho 1992).

This study was conducted to evaluate the relationships between the number of ovipositions by $C$. flavipes on $D$. saccharalis and the number of C. flavipes descendants; the sex-ratio of C. flavipes emerging from $D$. saccharalis larvae submitted to one or two ovipositions; and the relationship between the number of ovipositions by $C$. flavipes on $D$. saccharalis and the number of viable $C$. flavipes larvae and pupae.

\section{Material and Methods}

Adults of C. flavipes, D. saccharalis larvae and artificial diet were obtained from the mass rearing laboratory of the São João SugarMill (Araras, SP). Fifth instar larvae were selected by measuring cephalic capsules with a micrometric ocular. Females of C. flavipes used to parasitize $D$. saccharalis larvae were mated 24 hours after emergence.

Experiment 1. Each female of $C$. flavipes was introduced into a Petri dish $(6.5 \mathrm{~cm}$ diameter $)$, containing one host larva. Sixty six $D$. saccharalis larvae were used. After parasitization each larva was transferred to another dish containing artificial diet, maintained at $27 \pm$ $1{ }^{\circ} \mathrm{C}$, photophase of 14 hours and $70 \pm 10 \%$ $\mathrm{RH}$. The emergence time of the parasitoid larvae was recorded, considering the interval between the first and the last larval emergence. The parasitoid larvae that pupated were placed in $30 \mathrm{ml}$ vials, covered with tulle for observation of adult emergence. Adults were fed with a solution of distilled water and honey (1:1) and maintained at the conditions previously described. After emergence, the number of parasitoid males and females was determined to estimate the sex-ratio. Longevity and the number of non-viable larvae and pupae of the parasitoid were recorded.

Experiment 2. Seventy $D$. saccharalis larvae were used and each $C$. flavipes female was allowed to oviposit twice in the same host. Time of emergence of parasitoid (larvae and adults), sex-ratio, number of non-viable larvae and pupae, and longevity of adults were estimated.

The Mann-Whitney U test was used to compare data related to the number of adult parasitoids, the sex-ratio and the number of non-viable larvae and pupae from $D$. saccharalis larvae submitted to one or two ovipositions. The t-test was used to compare the mean values of longevity recorded for parasitoids derived from $D$. saccharalis larvae oviposited once or twice by the parasitoid.

\section{Results and Discussion}

There was a significant difference in the number of parasitoids that emerged from hosts that were parasitized once or twice $(\mathrm{U}=1779$, $50 ; \mathrm{P}=0,021 ; \alpha=5 \%)$. The mean number of emerged parasitoids, when two ovipositions were recorded, was greater in relation to the ones that emerged from hosts submitted to only one oviposition (Table 1). In this case, the superparasitism was benefic, because females were predisposed to lay eggs in hosts already 
Table 1. Development period, number of males and females, sex-ratio, number of nonviable larvae and pupae, number of adults and adult longevity of Cotesia flavipes reared in Diatraea saccharalis larvae submitted to one and two ovipositions.

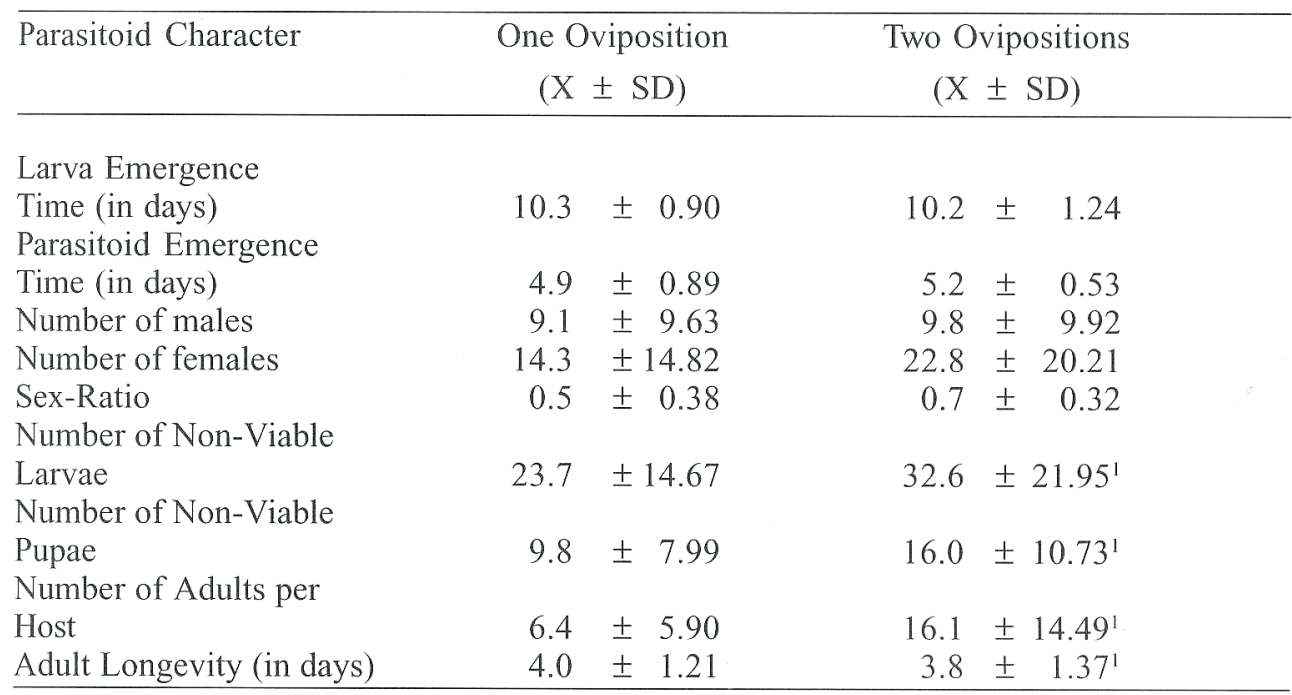

${ }^{1}$ Values that presented significant differences between the two experimental groups (see explanations in the text).

parasitized (theorically less adequate to oviposition). Another important advantage of the superparasitism could be the time and economy of energy that would be wasted to discriminate and reject parasitized hosts (Hughes 1979, apud Waage 1989). The occurrence of this type of parasitism can be explained by the low density of available hosts, leading females to increase the number of offspring in each host, what would decrease the food available and larval size.

Mean longevities values for adult parasitoids from one oviposition (4.0 days) and two (3.8 days) were also different (Table $1, \mathrm{t}=19,76$; $\mathrm{P}=0 ; \alpha=5 \%)$. The lower longevity when two ovipositions occurred was probably caused by competition inside the host. The increase of competition inside the host decreases parasitoid fitness in terms of reproduction, host search, dispersion and survival (longevity) (Waage 1989).
The mean number of larvae that did not complete their development inside the host was also different between the two groups

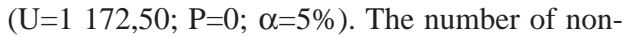
viable parasitoid larvae was greater when two ovipositions were performed in the same host (Table 1). The same occurred with the mean number of non-viable pupae $(\mathrm{U}=1503$; $\mathrm{P}=0 ; \alpha=5 \%)$. These results are similar to the ones obtained by Beg \& Inayatullah (1980). In intraspecific competition, as in this case, the mortality of immature stages usually increases considerably (Ikawa \& Okabe 1985).

The sex-ratio was the only factor that was not influenced by the number of ovipositions ( $U=2000 ; \mathrm{P}=0,176 ; \alpha=5 \%$ ) (Table 1). Three hypotheses can be raised to explain this equality: the sex-ratio would be independent from superparasitism and would not be altered in the total of the two ovipositions; there would be a difference in the mortality by sex, that is, one 
of the sexes would be more efficient to compete for food, acting on the sex-ratio and making it equal (this mortality would correct the possible distortions of the sex-ratio of 1 and 2 ovipositions); the female would not control the distribution of males and females in its progeny, like happens with C. glomerata, that has greater laying speed, making impossible the choice of sex in its progeny (Ikawa \& Okabe 1985).

Results of this research indicate that the suggestion of using $D$. saccharalis parasitized twice, to optimize the maintenance of $C$. flavipes in the laboratory to facil itate massal rearing(Gobbi et al. 1993,1994), should beviewed with caution, because a decrease in parasitoid fitness was observed when the host was superparasitized.

\section{Acknowledgements}

To the advisory committee of the São João Sugar-Mill (Araras, SP) by the provision of the material used; to Prof . Silvio Govone (Department of Statistics - UNESP) and Júlio C. Ribeiro (Department of Ecology - UNESP) for suggestions.

\section{Literature Cited}

Alam, M.M., F.D. Bennet \& K.P. Carl. 1971. Biological control of Diatraea saccharalis (E) in Barbados by Apanteles flavipes Cam. and Lixophaga diatraeae T. T. Entomophaga 16:151-158.

Beg, M. N. \& C. H. Inayatullah. 1980. Studies on Apanteles flavipes a parasite of graminaceous borers. Pakistan J. Agri. Res. 1: 146-152.

Botelho, P. S. M. 1992. Quinze anos de controle biológico de Diatraea saccharalis utilizando parasitóides. Pesq. Agropec. Bras. 27:255-262.
Botelho, P. S. M., N. De Gaspari, N. Macedo, L. C. Almeida, J. R. Araújo \& S. M. S. S. Araújo. 1983. Control of Diatraea saccharalis with Apanteles flavipes. In Congr. Int. Soc. Sugar CaneTechnol., Havana. Proc. 2:926-933.

Cueva, M. C., G.A.Ayquipa \& V. B. Mescua. 1980. Estudios sobre Apanteles flavipes (Cameron) introducido para controlar Diatraea saccharalis (F.) en el Peru. Rev. Per. Entomol. 23:73-76.

van Dijken, M. J. \& J. K. Waage. 1987. Self and conspecific superparasitism by the egg parasitoid Trichograma evanescens. Entomol. Exp. Appl. 43:183-192.

Doutt, R. L. 1959. The biology of parasitic hymenoptera. Annu. Rev. Entomol. 4:161 -182.

Galichet, F. F. 1971. Introdución y cria de Apanteles flavipes Cameron en Las Antilhas Francesas. Rev. Per. Entomol. 14: 373-375.

Gallo, D. 1980. Situação do controle biológico da broca da cana-de-açúcar no Brasil. An. Soc. Entomol. Brasil 9:303-308.

Gifford, J. R. \& G. A. Mann. 1967. Biology, rearing and trial release of Apanteles flavipes in the Florida Everglades to control the sugar cane borer. J. Econ. Ent. 60: 44-47.

Gobbi, N. \& M. C. A. Cunha. 1983. Observações preliminares referentes ao relacionamento entre a lagarta de Ascia monuste orseis (Godart, 1818) (Lepidoptera: Pieridae) e seu parasita Apanteles ayerzai (Brethes, 1920) (Hymenoptera: Braconidae). Naturalia 8:193-196.

Gobbi,N.,J.Chaud-Netto,J.A.F.Diniz-Filho, S.M.T. Tornisielo, L.C.Almeida \& S.L. 
Nazareth. 1993. Estudo do relaciona-mento entre Cotesia flavipes Cameron (1891) e Diatraea saccharalis F. (1794). I. Efeito do parasitismo no consumo de lagartas de $4^{\circ}$ instar. Naturalia 18:201-203.

Gobbi,N.,J. Chaud-Netto,J.A. F. Diniz-Filho, S. M. T. Tornisielo, L. C.Almeida \& S. L. Nazareth. 1994. Estudo do relacionamento entre Cotesia flavipes Cameron (1891) e Diatraea saccharalis E (1794). II. Efeito do parasitismo no consumo de lagartas de $5^{\circ}$ instar.An. Soc. Entomol. Brasil 23:45-49.

Hagley, E.A. C. \& D. Barber.1986. Preference of Pholetesor ornigis (Hym.: Braconidae) for the sap-feeding larvae of its host, the spotted tentiform leafminer, Phyllonorycter blancardella (Lep.: Graciliariidae). Entomophaga 31:393-395.

Hailemichael, Y., J. W. Smith Jr. \& R. N. Wiedenmann. 1994. Host-finding behavior, host acceptance, and host suitability of the parasite Xanthopimpla stemmator. Entomol. Exp. Appl.71:155-166.

Hebert, C. \& C. Cloutier. 1990. Host instar as a determinant of preference and suitability for two parasitoids attacking late instars of the spruce budworm (Lep.: Tortricidae). Ann. Entomol. Soc. Am. 83:734-741.

Hofsvang,T. 1990. Discrimination between unparasitized and parasitized hosts in hymenopterous parasitoids. Acta Entomol. Bohemoslov. 87:161-175.

Hopper, K.R. \& E.C. King. 1984. Preference of Microplitis croceips (Hymenoptera: Braconidae) for instars and species of Heliothis (Lepidoptera: Noctuidae). Environ. Entomol. 13:1145-1150.
Ikawa, T. \& H. Okabe. 1985. Regulation of egg number per host to maximize the reproductive success in the gregarious parasitoid Apanteles glomeratus L. (Hymenoptera: Braconidae). Appl. Ent. Zool. 20:331-339.

Lawrence, P. O. \& D. Akin. 1990. Virus-like particles from the poison gland of the parasitic wasp Biosters longicaudatus (Hym.: Braconidae), Can. J. Zool. 68:539-546.

Macedo, N., J. R.Araujo \& P. S. M. Botelho. 1993. Sixteen years of biological control of Diatraea saccharalis (Fabr.) (Lepidoptera: Pyralidae) by Cotesia flavipes (Cam.) (Hymenoptera: Braconidae) in the State of São Paulo, Brasil. An. Soc. Entomol. Brasil 22:441-448.

Sato,Y. 1980. Experimental studies on parasitization by Apanteles glomemtus. V Relationship between growth rate of parasitoid and host age at the time of oviposition. Entomophaga 25:123-128.

Stoltz, D. B. \& D. Guzo. 1986. Apparent haemocytic transformation associated with parasitoid induced inhibition of immunity in Malacosoma distria larvae. J. Insect Physiol. 32:377-388.

Vinson, S. B. \& G, F. Iwantsch. 1980. Host suitability for insect parasitoids. Annu. Rev. Entomol. 25:397-419.

Waage, J. K. 1989. Family planning in parasitoids: adaptive patterns of progeny and sex-allocation, p. 63-95. In Waage, J. \& D. Greathead, Insect Parasitoids. San Diego Academic Press, 389p.

Received 27/XII/95. Accepted 28/1/97. 